\title{
New Features in Neurology
}

\author{
Robert C. Griggs, MD; and Kathleen M. Pieper
}

The Cover: The AAN logo. With this issue, Neurology has adopted the new American Academy of Neurology logo that identifies our society. Changes in typeface on the cover correspond to identity changes that the AAN has for all its publications. Other minor changes in the journal, such as more prominent section titles for Editorials, Brief Communications and other departments, will make it easier to identify a particular section.

For our authors and peer reviewers. To keep pace with the ever-increasing speed of the electronic age, Neurology has been and will be making changes to our review processing, including receiving, reviewing, and transmitting papers electronically. With the advent of the Internet and e-mail, all steps of the editorial process are accelerated. The Neurology editorial office has a sophisticated manuscript-tracking database; we have not yet moved to a Web-based manuscript reviewing system. We are currently considering options and will soon implement a program once we can assure our authors and reviewers an efficient and user-friendly formula. Until we move to a Web-based system, we are providing the Neurology review sheet on our home page. Go to www.neurology. org and click on "For Peer Reviewers." This will bring reviewers to instructions for downloading an MS Word or a .pdf format Review sheet. Strict confidentiality is maintained. We expect to have an automated author inquiry system within the next 12 months.

Ombudsman report. In this issue, we are publishing our first Ombudsman's Report. Dr. Jack Whisnant was appointed Neurology Ombudsman in 2000. Dr. Whisnant fields all inquiries from complainants about process in the editorial office. These complaints take all forms and he has recounted them here. The complaints deal with lapses in the actual editorial process rather than editorial bias issues. Dr. Whisnant has made helpful recommendations, which the journal editorial office has implemented, to improve and clarify our editorial process for authors.

Patient page. In the July 9 issue of Neurology Online, we plan to publish our first patient page.
This page will be developed in collaboration with Robin Brey, MD, Chair of the Patient and Public Information Committee of the AAN. Beginning as an online feature, the Patient Page will summarize an article that has direct applicability to the improvement of patient care. Practicing neurologists can print out the patient page as a service to their patients.

Disclosure in clinical trials: Financial and nonfinancial. Neurology publishes many important randomized, controlled clinical trials. Many of these trials are supported partly or entirely by industry. Due to frequent industry involvement in research, Neurology has already taken steps to insure that our readers are given full disclosure of financial arrangements between the sponsors of the study and the authors. We are continuously updating our Information for Authors to outline the author's responsibility for such disclosures. All authors must sign an Author Disclosure Form to submit to Neurology. Authors are also responsible for disclosing, in detail, their relationship and financial arrangements on the title page of their paper and in the covering letter for the submission. They are also responsible for making sure that their final article reflects the financial disclosures in an acknowledgment.

In the February 12 issue, Neurology will be copublishing an editorial written by the editors of 13 neurology journals dealing with nonfinancial conflicts of interest between authors and corporate sponsors. Issues of control and complete access to all data, conduct of statistical studies and analyses, manuscript preparation, and decisions to publish are of increasing importance and concern. Corporate sponsors must not be allowed to influence publication, or indeed to prevent it, especially when the data are not supportive of their product. These issues have been addressed in recent editorials in JAMA and the New England Journal of Medicine. ${ }^{1,2}$ Along with a financial disclosure form, Neurology will soon request authors submit a nonfinancial disclosure form indicating that they accept full responsibility for the conduct of the study, had access to all the data, and had the authority to publish it. This information will be required before the review process is initiated. 
Change in supplement policy. A recent Neurology supplement used the term "guidelines" in the title and in the publication. Guidelines are developed by the AAN task forces and a number of subcommittees and have received extensive input from multiple sources. They are also peer reviewed by Neurology. The term "guidelines" (and similar wording) is not appropriate for supplements (or other non-AAN peer-reviewed papers).

Changes in Information for Authors. We have recently made some changes to the Information for Authors. ${ }^{3}$ We have changed Neurology's policy that authors of abstracts submitted to AAN meetings must first submit to Neurology or obtain permission from Neurology to submit elsewhere. We still encourage authors to submit their work to Neurology. Neurology's Editorial Board believes that Neurology is sufficiently competitive to receive the best clinical papers in our field.

A section has been added regarding duplicate or redundant publication. This year, we have had authors submit material that had already been submitted to or published in another journal. Vigilant peer reviewers have picked up the redundancies. We have clearly outlined our policy and sanctions in the recently updated Information for Authors.

We have added a section and a reference regarding Genetic Association studies based on a Neurology editorial. ${ }^{4}$ We have also added an author checklist that specifies all materials needed for initial submission.

Videos will now be considered for online publication. Authors must submit the video file on CD-ROM, which will be peer-reviewed with the associated manuscript. If the manuscript is accepted, the video will be accessible online and mentioned in the print journal. Format and submission requirements are detailed in the updated Information for Authors.

\section{References}

1. DeAngelis CD, Fontanarosa PB, Flanagin A. Reporting financial conflicts of interest and relationships between investigators and research sponsors. JAMA 2001;286:89-91.

2. Davidoff F, DeAngelis CD, Drazen, JM, et al. Sponsorship, authorship and accountability. N Engl J Med 2001;345:825827.

3. Neurology Information for Authors. Available at: www. neurology.org.

4. Bird TD, Jarvik GP, Wood NW. Genetic association studies: genes in search of diseases. Neurology 2001;57:1153-1154. 


\section{Neurology}

New Features in Neurology

Robert C. Griggs and Kathleen M. Pieper

Neurology 2002;58;3-4

DOI 10.1212/WNL.58.1.3

This information is current as of January 8, 2002

\section{Updated Information \& Services}

\section{References}

Citations

Permissions \& Licensing

Reprints including high resolution figures, can be found at: http://n.neurology.org/content/58/1/3.full

This article cites 3 articles, 1 of which you can access for free at: http://n.neurology.org/content/58/1/3.full\#ref-list-1

This article has been cited by 1 HighWire-hosted articles: http://n.neurology.org/content/58/1/3.full\#\#otherarticles

Information about reproducing this article in parts (figures,tables) or in its entirety can be found online at:

http://www.neurology.org/about/about_the_journal\#permissions

Information about ordering reprints can be found online:

http://n.neurology.org/subscribers/advertise

Neurology ${ }^{\circledR}$ is the official journal of the American Academy of Neurology. Published continuously since 1951, it is now a weekly with 48 issues per year. Copyright. All rights reserved. Print ISSN: 0028-3878.

Online ISSN: 1526-632X.

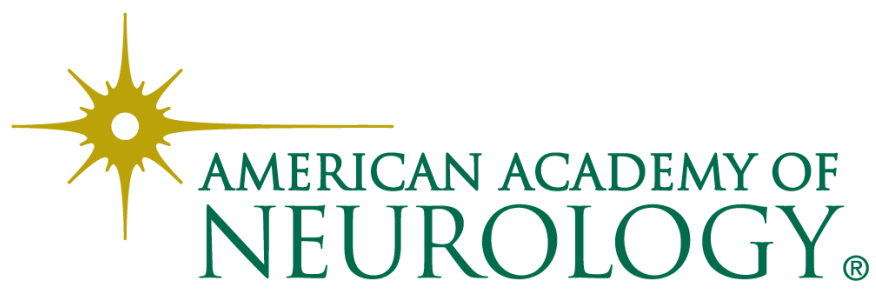

